\title{
EKSPERIMENTASI PEMBELAJARAN INTERAKTIF SETTING KOOPERATIF (PISK) DAN STUDENT TEAM ACHIEVEMENT DIVISION (STAD) PADA MATERI PELUANG DITINJAU DARI AKTIVITAS BELAJAR SISWA TAHUN PELAJARAN 2012/2013
}

\author{
Fhela Vhantoria Ningrum ${ }^{1}$, Riyadi $^{2}$, Mania Roswitha $^{3}$ \\ ${ }^{1}$ Prodi Magister Pendidikan Matematika, PPs Universitas Sebelas Maret Surakarta \\ ${ }^{2}$ Prodi Magister Pendidikan Matematika, PPs Universitas Sebelas Maret Surakarta \\ ${ }^{3}$ Jurusan Matematika, FMIPA Universitas Sebelas Maret Surakarta \\ E-mail : riavhantoria@yahoo.com ${ }^{1)}$
}

\begin{abstract}
The aim of the research was to determine the effect of PISK, STAD and conventional approach to the mathematics achievement viewed from student activities. This research was a quasi experimental using $3 \times 3$ factorial design. The populations of the research were all students of senior high school in Sukoharjo Regency. The sampel was 9 classes and it was taken using stratified random sampling technique. The instruments used to collect data were student activities questionnaire and mathematics achievement test. The requirements test for data included the population normality test using Lilliefors method and the population homogenity variance test using Bartlett method. The balance test toward student's early ability in mathematics data using unbalance one-way analysis of variance and it was concluded that experimental and control classes had balance prior knowledge in mathematics. The testing of hypotesis using unbalance two-way analysis of variance. The conclusion of this research shows as follows. (1) Students taught by PISK cooperative learning model had better mathematics achievements than students taught by STAD cooperative learning model and conventional model. In addition, STAD cooperative learning model and conventional model gave the same mathematics achievement. (2) Students in high activity had better mathematics achievement than students in middle and low activity; also students in middle activity had better mathematics achievements than students in low activity. (3) There was an interaction between learning model and activity toward mathematics achievement.
\end{abstract}

Keywords: PISK, STAD, Conventional, Student Activities, Mathematics Achievement.

\section{PENDAHULUAN}

Matematika merupakan salah satu ilmu yang sangat berperan dalam perkembangan ilmu pengetahuan dan teknologi. Dalam perkembangannya, pembelajaran matematika di Indonesia belum memuaskan. Pada Ujian Nasional tahun 2010/2011 ternyata ratarata nilai mata pelajaran matematika 
mempunyai rentang yang cukup jauh antara nilai tertinggi dan terendah. Selain itu dilihat dari daya serap siswa pada Ujian Nasional tahun 2010/2011 masih rendah, khususnya pada kompetensi menggunakan kaidah pencacahan/permutasi/kombinasi untuk menyelesaikan masalah yang terkait dan menghitung peluang suatu kejadian. Hal tersebut menunjukkan bahwa siswa mengalami kesulitan belajar yang berakibat pada daya serap atau penguasaan yang rendah sehingga prestasi belajar pun rendah.

Dalam

pembelajaran

matematika yang menjadi dasar pemikiran adalah bahwa para siswa memasuki kelas dengan pengetahuan, kemampuan, dan motivasi yang sangat beragam sehingga kegiatan pembelajaran perlu sebuah model pembelajaran yang lebih memberdayakan siswa secara aktif. Kegiatan pembelajaran yang baik, apabila guru mempersiapkan perencanaan dengan matang baik kelengkapan alat-alat pembelajaran seperti materi pelajaran maupun penggunaan model pembelajaran yang tepat digunakan sehingga dapat meningkatkan hasil belajar.

Pembelajaran dewasa ini, walaupun tidak bisa dikatakan untuk semua pembelajaran, masih banyak pembelajaran di sekolah-sekolah yang masih menggunakan model pembelajaran konvensional. Menurut Kusnandar (2007: 328), sifat pembelajaran konvensional lebih berpusat pada guru sehingga pelaksanaannya kurang memperhatikan kesuluruhan situasi belajar. Selain itu, siswa tidak ikut terlibat secara langsung dalam suatu pembelajaran, siswa menjadi kurang fokus, bosan, bahkan mengantuk saat jam pelajaran. Dalam kondisi seperti ini, guru dituntut untuk lebih kreatif dalam mengembangkan model pembelajaran sehingga siswa tidak merasa bosan dan tertekan selama pembelajaran berlangsung. Salah satu alternatif untuk mengatasi masalah yang ada berupa penerapan model pembelajaran lain yang lebih mengutamakan keaktifan siswa dan memberi kesempatan siswa untuk mengembangkan potensinya secara maksimal. Model pembelajaran yang dapat digunakan salah satunya adalah model pembelajaran kooperatif yang lebih menekankan pada keaktifan siswa dan kerjasama dalam suatu kelompokkelompok kecil yang heterogen untuk menyelesaikan suatu permasalahan. Dyson dan Grineski (Attle dan Baker, 2007: 78) menyatakan bahwa kelas yang menggunakan pembelajaran kooperatif dengan tim heterogen mampu mendorong siswa dalam interaksi positif guna mencapai tujuan tim. Beberapa model pembelajaran kooperatif yang dapat digunakan guru untuk menyampaikan materi pelajaran diantaranya Student Team Achievement Division (STAD), Problem Based Learning $\quad(P B L), \quad$ Pembelajaran 
Interaktif Setting Kooperatif (PISK), dan sebagainya.

Menurut Tanwey Gerson Ratumanan (2002), model Pembelajaran Interaktif Setting Kooperatif (PISK) merupakan hasil dari model modifikasi pembelajaran interaktif pada pembelajaran kooperatif yang menekankan pada interaksi siswa secara luas, yakni siswa (StudentStudent $=S-S$ ), siswa-bahan ajar (Student-Learning Material $=S-L M$ ), siswa-guru (Student-Teacher $=S-T$ ), siswa-bahan ajar-siswa (StudentLearning Material-Student $=S-L M-S)$, dan siswa-bahan ajar-guru (StudentLearning Material-Teacher $=S-L M-T$ ). Interaksi siswa sangat penting bagi upaya konstruksi pengeta huan, peningkatan kemampuan akademis, peningkatan kecakapan sosial, dan sebagainya. Menurut Davidson, dkk (Baroody, 1993), interaksi siswa penting untuk mengkonstruksi pengetahuan matematika, mengembangkan pemecahan masalah dan kompetensi berpikir, mendorong kepercayaan, dan perolehan kecakapan sosial.

Salah satu pembelajaran kooperatif yang lainnya adalah Student Team Achievement Division (STAD) yang menuntut siswa untuk memiliki kemampuan dalam berkomunikasi dan keterampilan proses berkelompok (group process skills) sehingga siswa dapat mengkonstruksi pemahamannya terhadap suatu konsep. Rai (Khan dan
Inamullah, 2011: 211) mengungkapkan bahwa STAD menimbulkan interaksi yang baik antar siswa, meningkatkan sikap positif terhadap pelajaran, dan harga diri serta meningkatkan keterampilan interpersonal.

Model pembelajaran Student Team Achievement Division (STAD) dan Pembelajaran Interaktif Setting Kooperatif (PISK) menekankan pada interaksi siswa yaitu, aktif melakukan kegiatan, aktif berpikir, menyusun konsep, dan memberi makna tentang hal-hal yang sedang dipelajari. Fungsi guru adalah memberikan penjelasan terbatas dalam bentuk pertanyaanpertanyaan yang merangsang berpikir siswa dan dapat mengarahkan siswa pada pemecahan masalah yang dihadapi, sehingga konsep matematika ditemukan oleh siswa itu sendiri.

Model Pembelajaran Interaktif Setting Kooperatif (PISK) dan model pembelajaran kooperatif tipe Student Team Achievement Divison (STAD) dapat menggali dan mengembangkan pengetahuan siswa secara kongkrit dan mandiri. Selain itu, proses pembelajaran akan lebih variatif, inovatif, dan konstruktif dalam merekonstruksi wawasan pengetahuan dan implementasinya sehingga dapat meningkatkan aktivitas dan kreativitas siswa.

Untuk meningkatkan pembelajaran matematika selain model pembelajaran yang digunakan juga tidak terlepas dari kemampuan yang 
berasal dari dalam diri siswa. Kemampuan tersebut dapat dilihat keaktifan siswa dalam proses pembelajaran. Siswa melakukan aktivitas belajar yang bervariasi, seperti mendengarkan, mencatat materi, bertanya, mengerjakan soal, menjawab pertanyaan guru, dan sebagainya. Sebagian siswa yang tidak tertarik dengan pelajaran matematika dan beranggapan bahwa matematika pelajaran yang sulit maka dapat dianggap bahwa kelompok ini adalah siswa dengan aktivitas belajar rendah. Aktivitas belajar yang rendah menyebabkan daya ingat terhadap suatu materi pelajaran rendah. Hal ini berpengaruh pada prestasi belajar matematika yang juga rendah. Sebaliknya, siswa dengan aktivitas belajar tinggi dalam proses pembelajaran sangat menyenangi pelajaran matematika dan terlibat aktif pada setiap kegiatan pembelajaran yang akan berpengaruh pada hasil belajar matematika yang lebih baik. Dipihak lain, siswa dengan aktivitas belajar sedang perlu adanya dorongan motivasi belajar agar mereka dapat terlibat lebih aktif dalam proses pembelajaran.

$$
\text { Melihat permasalahan }
$$

tersebut di atas, maka penulis tertarik untuk melakukan penelitian tentang penerapan model PISK, STAD, dan konvensional pada pembelajaran matematika ditinjau dari aktivitas belajar siswa, dimana penelitian ini belum pernah dilakukan oleh peneliti sebelumnya dan penelitian ini diharapkan mampu memberi kontribusi bagi peningkatan prestasi belajar matematika siswa.

Adapun tujuan penelitian ini adalah untuk mengetahui: (1) manakah yang memberikan prestasi belajar matematika lebih baik, model Pembelajaran Interaktif Setting Kooperatif (PISK), model pembelajaran kooperatif tipe Student Team Achievement Division (STAD), atau model pembelajaran konvensional, (2) manakah yang mempunyai prestasi belajar matematika lebih baik, siswa dengan aktivitas belajar tinggi, sedang, atau rendah, (3) pada masing-masing model pembelajaran matematika, manakah yang memberikan prestasi belajar matematika lebih baik, siswa dengan aktivitas belajar tinggi, sedang, atau rendah, (4) pada masing-masing aktivitas belajar siswa, manakah yang memberikan prestasi belajar matematika yang lebih baik, model Pembelajaran Interaktif Setting Kooperatif (PISK), model pembelajaran kooperatif tipe Student Team Achievement Division (STAD), atau model pembelajaran konvensional.

\section{METODE PENELITIAN}

Variabel dalam penelitian ini terdiri dari variabel bebas, yakni model 
pembelajaran matematika dan aktivitas belajar siswa, dan variabel terikat, yakni prestasi belajar matematika. Jenis penelitian ini adalah penelitian eksperimental semu dengan rancangan penelitian faktorial $3 \times 3$. Rancangan penelitian dideskripsikan pada Tabel 1 sebagai berikut.

Tabel 1. Rancangan Penelitian

\begin{tabular}{|c|c|c|c|}
\hline \multirow{3}{*}{$\begin{array}{c}\text { Model } \\
\text { Pembelajaran (A) }\end{array}$} & \multicolumn{3}{|c|}{ Aktivitas Belajar Siswa (B) } \\
\hline & Tinggi & Sedang & Rendah \\
\hline & $\left(b_{1}\right)$ & $\left(b_{2}\right)$ & $\left(b_{3}\right)$ \\
\hline Pembelajaran Interaktif Setting Kooperatif (PISK) $\left(\mathrm{a}_{1}\right)$ & $(\mathrm{ab})_{11}$ & $(a b)_{12}$ & $(a b)_{13}$ \\
\hline Student Team Achievement Division (STAD) $\left(\mathrm{a}_{2}\right)$ & $(\mathrm{ab})_{21}$ & $(a b)_{22}$ & $(a b)_{23}$ \\
\hline Konvensional $\left(\mathrm{a}_{3}\right)$ & $(\mathrm{ab})_{31}$ & $(a b)_{32}$ & $(a b)_{33}$ \\
\hline
\end{tabular}

Populasi dalam penelitian ini adalah seluruh siswa kelas XI SMA di Kabupaten Sukoharjo. Pengambilan sampel dilakukan dengan teknik stratified random sampling. Sampel dalam penelitian ini berjumlah 288 siswa, dengan rincian 192 siswa pada kelas eksperimen dan 96 siswa pada kelas kontrol.

Teknik pengumpulan data dalam penelitian ini menggunakan metode dokumentasi, angket, dan tes. Metode dokumentasi untuk mengumpulkan data kemampuan awal siswa. Metode angket untuk mengumpulkan data aktivitas belajar siswa. Metode tes untuk mengumpulkan data prestasi belajar matematika siswa. Uji coba instrumen tes meliputi validitas isi, tingkat kesukaran, daya pembeda, dan reliabilitas. Uji coba instrumen angket aktivitas belajar meliputi validitas isi, konsistensi internal, dan reliabilitas. $\mathrm{Uji}$ prasyarat meliputi uji normalitas

Aksioma Jurnal Pendidikan Matematika FKIP Univ. Muhammadiyah Metro populasi menggunakan metode Lilliefors dan uji homogenitas variansi populasi menggunakan metode Bartlett. Dengan $\alpha=0,05$, diperoleh simpulan bahwa sampel berasal dari populasi yang berdistribusi normal dan mempunyai variansi yang homogen. Uji keseimbangan terhadap data kemampuan awal matematika menggunakan analisis variansi satu jalan sel tak sama diperoleh simpulan bahwa kelas eksperimen dan kelas kontrol mempunyai kemampuan awal matematika yang seimbang. Pengujian hipotesis menggunakan analisis variansi dua jalan dengan sel tak sama.

\section{HASIL PENELITIAN DAN PEMBAHASAN}

Rerata prestasi belajar menurut model pembelajaran dan kategori 
aktivitas belajar dapat dilihat pada datanya dapat dilihat pada Tabel 3 Tabel 2, sedangkan rangkuman analisis sampai dengan Tabel 2.

Tabel 2 Rerata Sel dan Rerata Marginal

\begin{tabular}{|c|c|c|c|c|}
\hline \multirow{2}{*}{$\begin{array}{c}\text { Model } \\
\text { Pembelajaran }\end{array}$} & \multicolumn{3}{|c|}{ Aktivitas Belajar } & $\begin{array}{c}\text { Rerata } \\
\text { Marginal }\end{array}$ \\
\cline { 2 - 4 } & Tinggi & Sedang & Rendah & 76,8750 \\
\hline PISK & 80,7000 & 72,2285 & 77,3333 & 76,953 \\
\hline STAD & 68,4137 & 75,2631 & 61,2413 & 68,9583 \\
\hline Konvensional & 76,5714 & 66,8936 & 59,2857 & 66,7916 \\
\hline Rerata Marginal & 75,7777 & 71,1000 & 64,8718 & \\
\hline
\end{tabular}

Tabel 3 Rangkuman Analisis Variansi

\begin{tabular}{|c|c|c|c|c|c|c|}
\hline Sumber & $J K$ & $d k$ & $R K$ & $F_{\text {obs }}$ & $F_{\alpha}$ & Keputusan Uji \\
\hline Baris $(A)$ & 4662,715 & 2 & 2331,358 & 12,5382 & 3,00 & $H_{0}$ ditolak \\
\hline Kolom $(B)$ & 3902,526 & 2 & 1951,263 & 10,494 & 3,00 & $H_{0}$ ditolak \\
\hline Interaksi $(A B)$ & 4611,394 & 4 & 1152,849 & 6,2001 & 2,37 & $H_{0}$ ditolak \\
\hline Galat $(G)$ & 51877,24 & 279 & 185,9399 & - & - & - \\
\hline Total & 65053,88 & 287 & - & - & - & - \\
\hline
\end{tabular}

Berdasarkan rangkuman analisis variansi diperoleh hal-hal berikut.

1. ditolak, hal ini berarti terdapat pengaruh antar masing-masing kategori model pembelajaran terhadap prestasi belajar matematika.

2. ditolak, hal ini berarti terdapat perbedaan pengaruh antar masingmasing kategori aktivitas belajar terhadap prestasi belajar matematika.
3. ditolak, hal ini berarti terdapat interaksi antara model pembelajaran dan kategori aktivitas belajar siswa terhadap prestasi belajar matematika. 
Tabel 4 Hasil Uji Komparasi Antar Baris Kolom

\begin{tabular}{|c|c|c|c|}
\hline$H_{0}$ & $F_{\text {obs }}$ & $F_{\text {tabel }}$ & $\begin{array}{c}\text { Keputusan } \\
\text { Uji }\end{array}$ \\
\hline$\mu_{1 .}=\mu_{2 .}$ & 16,25 & 6,00 & $H_{0}$ ditolak \\
\hline$\mu_{1 .}=\mu_{3 .}$ & 26,37 & 6,00 & $H_{0}$ ditolak \\
\hline$\mu_{2 .}=\mu_{3 .}$ & 1,21 & 6,00 & $\begin{array}{c}H_{0} \\
\text { diterima }\end{array}$ \\
\hline
\end{tabular}

Tabel 6 Hasil Uji Komparasi Antar Sel Sel pada Baris yang Sama

\begin{tabular}{|c|c|c|c|}
\hline$H_{0}$ & $F_{o b s}$ & $F_{\text {tabel }}$ & Kep. Uji \\
\hline $\begin{array}{l}\mu_{11}=\mu_{12} \\
\mu_{11}=\mu_{13} \\
\mu_{12}=\mu_{13}\end{array}$ & $\begin{array}{l}7,24 \\
0,84 \\
1,84\end{array}$ & $\begin{array}{l}15,52 \\
15,52 \\
15,52\end{array}$ & $\begin{array}{l}H_{0} \text { diterima } \\
H_{0} \text { diterima } \\
H_{0} \text { diterima }\end{array}$ \\
\hline $\begin{array}{l}\mu_{21}=\mu_{22} \\
\mu_{21}=\mu_{23} \\
\mu_{22}=\mu_{23}\end{array}$ & $\begin{array}{l}4,17 \\
4,03 \\
17,47\end{array}$ & $\begin{array}{l}15,52 \\
15,52 \\
15,52\end{array}$ & $\begin{array}{l}H_{0} \text { diterima } \\
H_{0} \text { diterima } \\
H_{0} \text { ditolak }\end{array}$ \\
\hline $\begin{array}{l}\mu_{31}=\mu_{32} \\
\mu_{31}=\mu_{33} \\
\mu_{32}=\mu_{33}\end{array}$ & $\begin{array}{c}7,34 \\
19,37 \\
5,48\end{array}$ & $\begin{array}{l}15,52 \\
15,52 \\
15,52\end{array}$ & $\begin{array}{l}H_{0} \text { diterima } \\
H_{0} \text { ditolak } \\
H_{0} \text { diterima }\end{array}$ \\
\hline
\end{tabular}

Berdasarkan hasil uji komparasi diperoleh hal-hal berikut.

1. Dari hasil uji komparasi antar baris diperoleh bahwa prestasi belajar siswa yang dikenai model PISK lebih baik dibandingkan dengan prestasi belajar siswa yang dikenai model STAD dan model konvensional. Siswa yang dikenai Aksioma Jurnal Pendidikan Matematika FKIP Univ. Muhammadiyah Metro
Tabel 5 Hasil Uji Komparasi Antar

\begin{tabular}{|c|c|c|c|}
\hline$H_{0}$ & $F_{\text {obs }}$ & $F_{\text {tabel }}$ & $\begin{array}{c}\text { Keputusan } \\
\text { Uji }\end{array}$ \\
\hline$\mu_{\cdot 1}=\mu_{\cdot 2}$ & 6,08 & 6,00 & $H_{0}$ ditolak \\
\hline$\mu_{\cdot 1}=\mu_{\cdot 3}$ & 26,86 & 6,00 & $H_{0}$ ditolak \\
\hline$\mu_{\cdot 2}=\mu_{\cdot 3}$ & 9,91 & 6,00 & $H_{0}$ ditolak \\
\hline
\end{tabular}

Tabel 7 Hasil Uji Komparasi Antar pada Kolom yang Sama

\begin{tabular}{|c|c|c|c|}
\hline$H_{0}$ & $F_{o b s}$ & $F_{o b s}$ & Keputusan Uji \\
\hline$\mu_{11}=\mu_{21}$ & 13,71 & 15,52 & $H_{0}$ diterima \\
$\mu_{21}=\mu_{31}$ & 4,38 & 15,52 & $H_{0}$ diterima \\
$\mu_{11}=\mu_{31}$ & 1,26 & 15,52 & $H_{0}$ diterima \\
\hline$\mu_{12}=\mu_{22}$ & 0,90 & 15,52 & $H_{0}$ diterima \\
$\mu_{22}=\mu_{32}$ & 7,95 & 15,52 & $H_{0}$ diterima \\
$\mu_{12}=\mu_{32}$ & 3,08 & 15,52 & $H_{0}$ diterima \\
\hline$\mu_{13}=\mu_{23}$ & 17,04 & 15,52 & $H_{0}$ ditolak \\
$\mu_{23}=\mu_{33}$ & 0,29 & 15,52 & $H_{0}$ diterima \\
$\mu_{13}=\mu_{33}$ & 21,12 & 15,52 & $H_{0}$ ditolak \\
\hline
\end{tabular}

model STAD mempunyai prestasi sama baiknya dengan prestasi belajar siswa yang dikenai model konvensional. Hasil ini sesuai dengan hipotesis penelitian karena model PISK memberikan kebebasan kepada siswa dalam pengeksplorasi pengetahuan serta interaksi siswa lebih luas 
dibanding model lainnya. Model konvensional erat kaitannya dengan model STAD. Hal ini dapat dilihat dari adanya penyajian informasi atau materi pelajaran, perbedaan hanya terletak pada adanya pemberian penghargaan pada kelompok.

2. Dari hasil uji komparasi antar kolom diperoleh prestasi belajar matematika siswa dengan aktivitas belajar tinggi lebih baik dibandingkan prestasi belajar matematika siswa dengan aktivitas belajar sedang dan rendah, dan prestasi belajar matematika siswa dengan aktivitas belajar sedang lebih baik dibandingkan siswa dengan aktivitas belajar rendah. Hasil ini sesuai dengan hipotesis penelitian karena semakin tinggi aktivitas belajar siswa maka semakin tinggi daya ingat terhadap materi pelajaran sehingga dapat membantu siswa mencapai tujuan pembelajaran seperti yang diinginkan.

3. Dari hasil uji komparasi antar sel pada baris yang sama diperoleh hal-hal berikut. a) Pada siswa yang dikenai model PISK, prestasi belajar matematika pada semua kategori aktivitas belajar sama baiknya. Hasil ini sesuai dengan hipotesis penelitian karena adanya perluasan interaksi serta langkahlangkah model PISK yang berakhir dengan adanya tes unit individu, hal tersebut memaksa siswa dengan kategori masing-masing aktivitas belajar untuk memperluas interaksi, menggali pengetahuan sebanyak-banyak serta turut serta dalam kegiatan diskusi secara maksimal. b) Pada siswa yang dikenai model STAD, prestasi belajar matematika siswa dengan aktivitas belajar tinggi sama baiknya dengan siswa dengan aktivitas belajar sedang maupun rendah dan prestasi belajar matematika siswa dengan aktivitas belajar sedang lebih baik dibandingkan siswa dengan aktivitas belajar rendah. Kurang sesuainya hasil analisis ini dengan hipotesis dikarenakan kurangnya kontribusi dari siswa dengan aktivitas belajar rendah. Selain itu, menurut Slavin (Miftahul Huda, 2011: 68) kendala utama pembelajaran kooperatif adalah diffusion of responsibility (penyebaran tanggung jawab) adalah suatu kondisi di mana beberapa anggota yang dianggap tidak mampu diabaikan oleh anggota-anggota lain yang lebih mampu. Hal tersebut berakibat siswa berprestasi tinggi akan mengarah pada kekecewaan karena peran anggota yang pandai lebih dominan sehingga interaksi siswa dan tanggung jawab individu berkurang yang berakibat pada prestasi belajar siswa dengan 
aktivitas belajar tinggi. c) Pada siswa yang dikenai model konvensional, prestasi belajar matematika siswa dengan aktivitas belajar tinggi lebih baik dibandingkan siswa dengan aktivitas belajar rendah. Prestasi belajar matematika siswa dengan aktivitas belajar tinggi sama baik dengan siswa aktivitas belajar sedang dan prestasi belajar matematika siswa dengan aktivitas belajar sedang sama baik dengan siswa aktivitas belajar rendah. Hasil ini tidak sesuai dengan hipotesis penelitian karena guru kurang mendorong partisipasi siswa yang berarti memotivasi semua anggota kelompok untuk memberikan kontribusi terhadap tugas kelompok.

4. Dari hasil uji komparasi antar sel pada baris yang sama diperoleh hal-hal berikut. a) Siswa dengan aktivitas belajar tinggi pada pembelajaran menggunakan model PISK, STAD, maupun konvensional memberikan prestasi belajar matematika yang sama baik. Hasil ini sesuai dengan hipotesis penelitian karena siswa dengan aktivitas belajar tinggi maka semakin tinggi keterlibatan siswa dalam proses belajar. Keterlibatan siswa memberikan daya ingat lama terhadap materi pelajaran yang dapat membantu siswa dalam mencapai tujuan pembelajaran seperti yang diinginkan. b) Siswa dengan aktivitas belajar sedang pada pembelajaran menggunakan model PISK, STAD, maupun konvensional memberikan prestasi belajar matematika yang sama baik. Hasil ini sesuai dengan hipotesis penelitian karena siswa dengan aktivitas belajar sedang masih memerlukan bantuan guru dalam menerangkan materi yang belum jelas. Selain itu, perlu adanya motivasi tambahan berupa penghargaan serta adanya kerjasama antar siswa yang dapat memacu aktivitas belajar siswa. c) Siswa dengan aktivitas belajar rendah pada pembelajaran menggunakan model PISK memberikan prestasi belajar matematika yang lebih baik daripada menggunakan model STAD dan model konvensional. Selain itu, siswa yang memiliki aktivitas belajar rendah pada pembelajaran menggunakan model STAD memberikan prestasi belajar matematika yang sama baik dengan menggunakan model konvensional. Hasil ini sesuai dengan hipotesis penelitian karena siswa dengan aktivitas belajar rendah membutuhkan bimbingan secara mendalam dalam memahami materi yang sedang diajarkan dan latihan soal. Hal ini diakibatkan siswa dengan aktivitas belajar rendah cenderung pasif 
serta kurangnya kerjasama yang dilakukan dalam proses pembelajaran, sehingga untuk mengkonstruksi pengetahuannya dibutuhkan bantuan guru sebagai pembimbing. Penerapan model PISK yang memberikan kebebasan kepada siswa dalam pengeksplorasi pengetahuan serta interaksi siswa lebih luas sehingga memungkinkan siswa terlibat aktif. Selain itu, tes unit pada setiap kali pertemuan membuat siswa dipaksa untuk memahami materi peluang yang baru saja diajarkan. Pada model STAD yang mendorong motivasi melalui pemberian penghargaan, maka pada siswa dengan aktivitas belajar rendah cenderung memberi penilaian negatif terhadap penghargaan karena dominannya penghargaan selalu didapatkan siswa dengan aktivitas belajar tinggi. Selain itu pada model pembelajaran konvensional, siswa dengan aktivitas belajar rendah kurang terlibat selama kegiatan pembelajaran karena model ini berpusat pada guru.

\section{KESIMPULAN DAN SARAN}

Berdasarkan hasil penelitian dan pembahasan, diperoleh simpulan berikut. (1) Prestasi belajar matematika siswa yang dikenai model PISK lebih baik dibandingkan siswa yang dikenai model STAD dan konvensional. Selain itu, prestasi belajar matematika siswa yang dikenai model STAD sama baiknya dengan siswa yang dikenai model konvensional. (2) Pada siswa yang dikenai model PISK, prestasi belajar matematika siswa dengan aktivitas belajar tinggi sama baiknya dengan siswa aktivitas belajar sedang maupun rendah dan prestasi belajar matematika siswa dengan aktivitas belajar sedang sama baiknya dengan siswa yang aktivitas belajarnya rendah. (3) Pada siswa yang dikenai model STAD, prestasi belajar matematika siswa dengan aktivitas belajar tinggi sama baiknya dengan siswa yang aktivitas belajarnya sedang maupun rendah dan prestasi belajar matematika siswa dengan aktivitas belajar sedang lebih baik dibandingkan siswa dengan aktivitas belajar rendah. Pada siswa yang dikenai model konvensional, prestasi belajar matematika siswa dengan aktivitas belajar tinggi lebih baik dibandingkan dengan siswa yang aktivitas belajarnya rendah, prestasi belajar matematika siswa yang memiliki aktivitas belajar tinggi sama baik dengan siswa aktivitas belajarnya sedang dan prestasi belajar matematika siswa dengan aktivitas belajar sedang sama baik dengan siswa aktivitas belajarnya rendah. (4) Siswa yang memiliki aktivitas belajar tinggi pada pembelajaran menggunakan model PISK, STAD, maupun konvensional 
memberikan prestasi belajar matematika yang sama baik. Siswa yang memiliki aktivitas belajar sedang dikoordinasikan dengan model PISK memberikan prestasi belajar yang sama dengan menggunakan model STAD dan konvensional. Selain itu, siswa yang memiliki aktivitas belajar sedang dikoordinasikan dengan model STAD memperoleh prestasi belajar yang sama baik dengan menggunakan model konvensional. Siswa dengan aktivitas belajar rendah pada model PISK memberikan prestasi belajar matematika yang lebih baik daripada model STAD dan konvensional. Selain itu, siswa dengan aktivitas belajar rendah pada model STAD memberikan prestasi belajar matematika yang sama baik dengan model konvensional.

Dalam rangka turut menyumbangkan ide dan wawasan berkaitan dengan peningkatan prestasi belajar matematika, maka penulis memberikan beberapa saran berikut. (1) Kepada guru mata pelajaran matematika hendaknya termotivasi untuk menerapkan model pembelajaran inovatif agar proses pembelajaran lebih mampu meningkatkan keterlibatan siswa dalam proses kegiatan pembelajaran. Pada proses pembelajaran, guru hendaknya lebih mendorong partisipasi siswa untuk memberikan kontribusi terhadap tugas kelompok. Selain itu, guru hendaknya lebih memperhatikan perbedaan karakteristik aktivitas belajar siswa, karena keterlibatan siswa dalam proses pembelajaran berpengaruh terhadap prestasi belajar siswa. (2) Kepada para peneliti hendaknya dapat melakukan penelitian lebih lanjut dengan memperdalam dan memperluas lingkup penelitian ini, yakni dengan mengembangkan model pembelajaran yang lebih inovatif dengan menambahkan variabel-variabel bebas yang turut mempengaruhi prestasi belajar siswa.

\section{DAFTAR PUSTAKA}

Attle, S. dan Baker, B. 2007. Cooperative Learning In a Competitive Environtment: Classrom Applications. International Journal of Teaching and Learning in Higher Education. Volume 19, Number 1, 77-83 ISSN 18129129.

Baroody, A. J. 1993. Problem Solving, Reasoning, and Communicating. Macmillan Publising, NewYork.

Khan, G. N. dan Inamullah, H. M. 2011. Effect of Student's Team Achievement Division (STAD) on Academic Achievement of Students. Canadian Center of Science and Education. Vol. 7, No. 12: 211-215.

Kusnandar. 2007. Guru Profesional Edisi Revisi. Jakarta: Rajagrafindo Persada.

Miftahul Huda. 2011. Cooperative Learning Metode, Teknik, 
ISSN 2442-5419 Vol. 3, No. 2 (2014) 77-88

Struktur, dan Model Penerapan. Yogyakarta: Pustaka Pelajar. dengan setting Kooperatif. Sura baya: PPS Universitas Surabaya.

Tanwey Gerson Ratumanan. 2002.

Model Pembelajaran Interaktif 